\title{
Prevalence and factors associated to cervical changes in units from the Single Health System
}

\author{
Prevalência e fatores associados às alterações cervicais \\ em unidades do Sistema Único de Saúde \\ Prevalencia y factores asociados a las alteraciones cervicales \\ en unidades del Sistema Único de Salud

\section{Indianara Carlotto Treco ${ }^{a}$ Valquíria Kulig Vieira ${ }^{a}$ Janaína Carla da Silva ${ }^{a}$ \\ Fernando Rodrigo Treco $^{b}$ Lirane Elize Defante Ferreto ${ }^{a, b}$ Léia Carolina Lucioa,b}

\section{How to cite this article:} Treco IC, Vieira VK, Silva JC, Treco FR, Ferreto LED, Lucio LC. Prevalence and factors associated to cervical changes in units from the Single Health System. Rev Gaúcha Enferm. 2021;42:e20200233. doi: https://doi.org/10.1590/19831447.2021.20200233
Universidade Estadual do Oeste do Paraná (UNIOESTE), Centro de Ciências da Saúde, Programa de Pós-graduação em Ciências Aplicadas à Saúde, Francisco Beltrão, Paraná, Brasil.

Universidade Estadual do Oeste do Paraná (UNIOESTE), Centro de Ciências da Saúde, Francisco Beltrão, Paraná, Brasil.

\section{ABSTRACT}

Objective: To estimate the prevalence and risk factors associated with cytopathological changes in the uterine cervix of women treated by the Unified Health System.

Method: This is a cross-sectional study carried out with 350 women, between 14 and 79 years old who underwent pap smear tests in heath units in Francisco Beltrão, Paraná. Cervical cytopathological analyses and a questionnaire were applied to obtain socioeconomic information, as well as data on sexual behavior, gynecological aspects, and life habits. Chi-square test and logistic regression with $p$ $<0.05$ were applied for statistical analysis.

Results: The prevalence of cervical changes was 3.4\% and the main categories found were low-grade cervical intraepithelial lesion, high-grade cervical intraepithelial lesion, and atypical cells of undetermined significance. From these, the first were present in 16.6\% of women under 25 years old. The multivariate analysis pointed at associations between previous results of the cytopathology test (OR $=25.693)$, smoking $(O R=7.576)$, and oral contraceptives $(O R=5.265)$ and the outcome.

Conclusion: Women with a history of previous cervical cytopathological abnormality, use of oral contraceptives, and smokers were more likely to have an abnormal result in the pap smear test.

Keywords: Cervical intraepithelial neoplasia. Papanicolaou test. Women's health. Tobacco. Contraceptives.

\section{RESUMO}

Objetivo: Estimar a prevalência e fatores de risco associados as alterações citopatológicas do colo uterino de mulheres atendidas pelo Sistema Único de Saúde.

Método: É um estudo transversal com 350 mulheres de 14 a 79 anos que realizaram exame Papanicolau em unidades de saúde de Francisco Beltrão, Paraná. Realizou-se análise citopatológica e aplicou-se um questionário com informações socioeconômicas, comportamento sexual, ginecológico e hábitos de vida. Para análise estatística foi feito teste Qui-quadrado e regressão logística $(p<0,05)$. Resultados: Prevalência das alterações cervicais foi 3,4\%, incluindo Lesão intraepitelial de baixo e alto grau e Atipias de significado indeterminado. Destas, a primeira teve $16,6 \%$ de frequência nas mulheres abaixo de 25 anos. A análise multivariada apontou associações entre resultado citopatológico anterior $(O R=25,693)$, hábito de fumar $(0 R=7,576)$ e anticoncepcional $(O R=5,265)$ com o desfecho.

Conclusão: Mulheres com história de alteração cervical, uso de anticoncepcional e fumantes possuem maiores chances de alterações no colo uterino.

Palavras-chave: Neoplasia intraepitelial cervical. Teste de Papanicolaou. Saúde da mulher. Tabaco. Anticoncepcionais.

\section{RESUMEN}

Objetivo: estimar la prevalencia y los factores de riesgo asociados con las alteraciones citopatológicas en cuello uterino de mujeres atendidas por el Sistema Único de Salud.

Método: Estudio transversal realizado con 350 mujeres, entre 14 y 79 años, que se sometieron a una prueba de Papanicolaou en unidades de salud de Francisco Beltrão, Paraná. Se realizó análisis citopatológicos cervicales y se aplicó un cuestionario para obtener informaciones socioeconómicas, ginecológicas, sobre conducta sexual y hábitos de vida. La prueba de chi-cuadrado y la regresión logística con $p<0.05$ fueron aplicadas para el análisis estadístico

Resultados: La prevalencia de alteraciones cervicales fue del $3,4 \%$ y las principales categorías encontradas fueron lesión intraepitelial de bajo grado, lesión intraepitelial de alto grado y atipias de significado indeterminado. De estos, el primero estuvo presente en el $16,6 \%$ de las mujeres menores de 25 años. El análisis multivariante señaló asociaciones entre el resultado citopatológico previo (OR= 25.693), el tabaquismo $(O R=7.576)$ y el consumo de anticonceptivos $(O R=5.265)$ con el resultado.

Conclusión: Las mujeres con antecedentes de alteraciones cervicales previas, uso de anticonceptivos orales, y fumadoras tienen más probabilidades de alterar el cuello uterino.

Palabras clave: Neoplasia intraepitelial cervical. Prueba de papanicolaou. Salud de la mujer. Tabaco. Anticonceptivos. 


\section{口INTRODUCTION}

On a global scale, cervical cancer is the fourth most incident and that causes the most mortality by cancer among women. There are nearly 311 thousand deaths a year due to this neoplasm ${ }^{(1)}$. In Brazil, it is the third most common type of cancer and the fourth greatest cause of deaths in the female population, after breast, colorectal, and lung cancers ${ }^{(2)}$.

The cytopathology test known as pap smear leads to a significant reduction of both the incidence and mortality due to cervical cancer, especially because it provides an early diagnosis for pre-invasive intra-epithelial cervical injuries ${ }^{(3)}$. The pap smear is considered to be the golden standard, since 1940, to detect cervical cancer. Sexually active women from 25 to 65 years old are examined every three years in countries like Canada, Belgium, Ireland, Italy, and France ${ }^{(3-4)}$. In Brazil, the Ministry of Health also recommends the exam in sexually active women from 25 to 65 years old, whether or not they were examined before. When no abnormality is detected after two consecutive years of testing, the interval increases to three years ${ }^{(2)}$.

Although the human papillomavirus (HPV) is the main predictive factor for the injuries and for cervical cancer, it is not al ways a sufficient cause. Other factors contribute for the natural history of the disease. These include the immunological response of the host, viral genetic profiles, the early beginning of sexual activities, multiple partners, a previous history of Sexually Transmitted Infections (STIS), the use of oral contraceptives (OC), smoking, nutritional deficiencies, low socioeconomic level of the host ${ }^{(5)}$, all of which are potential axes for interventions.

The early diagnosis of the cytopathology changes and of the early stages of the cervical cancer increases the chance of a cure, consequently reducing mortality ${ }^{(3)}$. Furthermore, the pap smear is a low cost, fast, and simple exam, which is made available for the female population by the Brazilian Single Health System, which is integrated to the national screening programs for cervical cancer in many other countries. More specifically, in the city of Francisco Beltrão, in the southwest of Paraná, where this research was carried out, information about epidemiology and its risk factors, as associated to cytopathology cervix alterations are not disseminated.

A study carried out with women in a the only Primary Health Care Unit in Francisco Beltrão found that overweight, alcohol consumption, exposure to pesticides, and a family history of cervical cancer (CC) were the risk factors associated to the incidence of some time of cervical alteration ${ }^{(6)}$. These results caught our attention, and we became interested in verifying the variables of exposure to know whether these are risk factors similar to ones reported in literature, since the characteristics present here are different from those found in other studies ${ }^{(7-8)}$ due to the fact that this is a countryside town, whose health system has a structure that is quite different from that of capitals or large urban centers. Thus, it is important to evaluate the risk factors for women who undergo exams to prevent CC, since the results will be useful to subsidize health interventions in small towns, in order to diminish the risks found and achieve information about the epidemiological profile of the population for actions to promote, protect, and recover health.

Brazil is a country with large territory and population, in addition to socioeconomic, cultural, and behavior diversity among individuals, even in regard to sex ${ }^{(9)}$. Up to this moment, we have no knowledge of the prevalence of cervical chances and potential elements that present risk to the female population of the small town $(<100,000$ people) of Francisco Beltrão, nor do we know whether these elements are similar or different from the rest of Brazil.

Normally, the adoption of strategic measures by public policies in programs for women's health are generalist, although Brazil is a heterogeneous country. Finding information about regional and local particularities for the prevalence of cervical changes and its associated risk factors can contribute to widen the effectiveness of actions that are already instituted or strengthen the need for redirecting it to a specific public. With this in mind, this study aimed at estimating the prevalence of risk factors associated with cytopathology changes in the cervix of women attended in health units from the SUS.

\section{METHOD}

this is a cross-sectional study carried out in October, November, and December 2017. The population of the study included women who underwent routine gynecology consultations in five health units from the Single Health System (SUS) in the city of Francisco Beltrão, Paraná. These units belong to four Family Health Strategies (ESF), from the districts of Antônio de Paiva Cantelmo, Cristo Rei, Industrial, and Pinheirinho. The other unit, the Instituto da Mulher (Women's Institute - IM) is also a reference for gynecology and obstetrics outpatient attention, and is located in the Cango district. The units were selected by convenience, as long as they accepted participating in the research, and were distributed as to represent the territory of the city. Following ethical principles, the study was approved by 
the Research Ethics Committee for Researches with Human Beings from the Universidade Estadual do Oeste do Paraná (CEP/UNIOESTE), under opinion 2.254.450. Participants were required to sign Free and Informed Consent Forms, in addition to specific Consent Forms for those below 18 years old.

Ages below 25 or above 64 yaers old are not the group recommended by the Ministry of Health to undergo the pap smear. However, these women, as long as sexually active, undergo examinations in the health units in Francisco Beltrão. A study carried out in cities in the state of Rio de Janeiro found that up to $12.4 \%$ adolescents had cases of cervix changes, especially considering low-grade squamous intraepithelial lesions (LSIL) ${ }^{(10)}$. In another work, authors reported an expressive presence of cervical cancer in women above 64 years old ${ }^{(11)}$. Therefore, women who are not in the age group considered by the Ministry can present cervix changes, and, thus, were also considered in the study. In 2017, there were 31,435 women from 14 to 79 years old in Francisco Beltrão, and this group was selected to estimate the sample of the study. The sample size was calculated using the software Statcalc, from the Epi-info software, version 7.2.2.6 (https:// www.cdc.gov/epiinfo/support/por/pt_downloads.html), considering a prevalence of $30 \%$ of a cytopathology exam presenting alterations $\mathbf{s}^{(7)}$, a degree of confidence of $95 \%$ and an absolute error rate of $5 \%$. Therefore, the minimal sample required was that of 320 women. This coupled with $10 \%$ of losses and refusals to participate, led to a final population of 350 participants.

To recruit the women, they were provided with information about the research and invited to participate. Those who agreed signed the Free and Informed Consent Form or the Consent Form. Were included only women who had already had sexual intercourse, regardless of their age or of whether they were sexually active. Those who had been through hysterectomies and pregnant women were excluded.

Each participant talked individually with the researcher or with a previously trained nurse, through a questionnaire ${ }^{(12)}$ with 22 questions. There were sociodemographic and economic questions, in addition to others about gynecology/ sexual behavior and lifestyle. Later, the biological material for the cytopathology cervix exam was collected. The cytological analyses were carried out according with the regular procedure of the Health Unite, using the pap smear exam kit (Kolplast). The sample was sent to the pathology laboratory of the city, which is certified by the SUS. The information about current and previous results were obtained in the System for Information on Cancer (SISCAN), a web platform from the Ministry of Health. Access to it was granted by the Municipal Secretariat of Health of Francisco Beltrão - PR. The results of the cytopathology analyses were based on the Bethesda classification terminology.

The depending variable of the study was the absence or presence of cytopathology changes as an outcome. The independent ones were grouped in socioeconomic (skin color, age, educational leve, marital status, and income), sexual/gynecological behavior (age at the time of the first sexual intercourse, number of sexual partners during life and new ones, parity, STI history, and life habits (use of OC, smoking or consume of alcohol, use of condoms, and immunization.

The statistical analysis were carried out using the software Software Statistical Package for the Social Sciences (SPSS), version 24.0. At first, a descriptive analysis was carried out to determine the frequency of socioeconomic independent variables, as well as those related to sexual/gynecological behavior and lifestyle. The quantitative variables of family income and age were categorized, since their data did not show normality even in a logarithmic scale. In the case of income, it was classified according with the criteria from the Brazilian Institute of Geography and Statistics (IBGE), based on the number of minimum wages received/month and grouping the population on the social classes: $B$ (from 5 to 15 minimum wages), C (from 3 to 5), D (from 1 to 3 ), and $\mathrm{E}$ (up to one).

Then, a bivariate analysis was carried out, comparing all independent variables with the dependent one, considering the outcome of presence or absence of alterations in the current cytopathology exam as calculated using the chisquared $\left(X^{2}\right)$ with a continuity correction. The variables with $p<0.20$ were put through a univariate logistic regression to verify how much each could explain, independently, the outcome. Later, those with statistical significance were put through a multivariate logistic regression analysis. The variables that would make up the probable multivariate model were inserted one by one, in growing order of statistical significance (considering $p<0.05$ ). The variables that defined the model not only continued to be significant, as they also showed odds ration and explanatory powers as defined by Cox \& Snell's $R$ squared $\left(R^{2}\right)$, to evaluate the quality of fit of the final model. 


\section{RESULTS}

The participants of this research were a total of 350 women from 14 to 79 years old, with a mean age of 41.4 years $( \pm 14)$. From these, most self-declared to be white (83.7\%) and 70.29\% stated to be married or in stable unions. Regarding their educational level, more than 65\% stated they had at least nine years formal education, while $14 \%$ had finished a higher education course. Considering their monthly family income, most were from the class D (59.4\%), with a mean income, in Brazilian reais, of $\mathrm{R} \$ 2,338.15( \pm 1,498.5)$. Considering the occupation/profession of these women, most were "House workers". In regard to their life habits, $44.29 \%$ of these women use $O C$ and $1 / 3$ use condoms in their sexual relations. Furthermore, the population has a low level of vaccination and, thus, is naturally more vulnerable to the HPV virus. Regarding their life habits, a few above than half do not drink alcoholic beverages and almost 80\% never smoked (Table 1).

Regarding the sexual behavior and gynecology aspects investigated, the prevalence of cytopathology changes in the cervix was of 3;4\% in the population analyzed, a total of 12 women. These changes were categorized as: lowgrade squamous intraepithelial lesions (LSIL), with 41.7\%; cervical high-grade squamous intraepithelial lesions (HSIL), and atypical squamous cells of undetermined significance (ASC-US), not excluding high-grade lesions), the latter having each $16.7 \%$ frequency. The following alterations were also observed: atypical glandular cells of undetermined significance, potentially non-neoplastic (AGC-US), atypical squamous cells of undetermined significance (ASC-US), possibly non neoplastic, and AGC-US+LSIL. All these had an 8.3\% frequency. Most alterations were observed in women from 25 to 49 years old, which is the age group to whom the pap smear is recommended. However, it stands out that two participants (16.6\%), of 19 and 21 years old, presented LSIL. Women above 64 years old, in turn, showed no abnormalities in the exam.

In regard to the other variables of this type, more than $2 / 3$ of women had their first sexual intercourse when 18 years old or younger. More than half the population (59.43\%) stated that they had sexual intercourse with two or more partners throughout their lives and $19.43 \%$ had more than one new sexual partner in the previous year. Regarding their parity, most women (74.57\%) had up to two children (Table 2 ) and $15.3 \%$ of participants had a pregnancy whose outcome was an abortion.

Considering the outcome, the result of the cytopathology cervix exam, the bivariate analysis (chi-squared test, $\left.X^{2}\right)$ of the data indicated that it could be related to variables whose significance was $<0.20$ (Tables 1 and 2). Among these, are the age group, the variables related to life habits, the use of oral contraceptives and smoking, in addition to variables related to sexual and gynecological behavior, such as the start of sexual activities, the number of sexual partners throughout one's life, the history of STIS (among them, the one caused by HPV), and previous cytopathology cervix exam results.

As these variables were incorporated in a univariate logistic regression analysis, they were preserved to create the potential regression model, with the exception of age group $(p=0.099)$ and the start of sexual activities $(p=0.996)$ (Table 3$)$.

Table 1 - Profile and analysis of the socioeconomic characteristics and life habits of women attended in the Health Unit according with the results of the cytopathology cervical exam, in the city of Francisco Beltrão, PR, Brazil, 2017.

\begin{tabular}{|c|c|c|c|c|}
\hline Categorized variables & $\begin{array}{c}\text { Study } \\
\text { population } \\
\left(n^{*}=350\right)\end{array}$ & $\begin{array}{c}\text { Normal } \\
\text { cytopathology } \\
\text { exam }(n *=338)\end{array}$ & $\begin{array}{c}\text { Abnormal } \\
\text { cytopathology } \\
\text { exam }\left(n^{*}=12\right)\end{array}$ & P-value \\
\hline Age group & & & & 0.155 \\
\hline Age $<38$ years old & $149(42.57 \%)$ & $141(94.6 \%)$ & $8(5.4 \%)$ & \\
\hline Age $\geq 38$ years old & $201(57.43 \%)$ & 197 (98.0\%) & $4(2.0 \%)$ & \\
\hline Marital status & & & & 0.493 \\
\hline Single & $104(29.71 \%)$ & $102(98.1 \%)$ & $2(1.9 \%)$ & \\
\hline Married and others & 246 (70.29\%) & 236 (95.9\%) & $10(4.1 \%)$ & \\
\hline
\end{tabular}


Table 1 - Cont.

$\begin{array}{cccc}\text { Categorized variables } & \begin{array}{c}\text { Study } \\ \text { population } \\ \left(n^{*}=350\right)\end{array} & \begin{array}{c}\text { Normal } \\ \text { cytopathology }\end{array} & \begin{array}{c}\text { Abnormal } \\ \text { cytopathology }\left(n^{*}=338\right) \\ \text { exam }\left(n^{*}=12\right)\end{array}\end{array}$

\section{Educational level}

0.735

$\leq 9$ years of formal study

$\begin{array}{lll}118(33.71 \%) & 115(97.5 \%) & 3(2.5 \%) \\ 232(66.29 \%) & 223(96.1 \% 0 & 9(3.9 \%)\end{array}$

$>9$ years of formal study

1.000

\section{Ethnicity}

White

Black and others

Monthly family income

$\begin{array}{lll}293(83.71 \%) & 283(96.6 \%) & 10(3.4 \%) \\ 57(16.29 \%) & 55(96.5 \%) & 2(3.5 \%)\end{array}$

Class E (up to one minimum wage)

$208(59.4 \%)$

$71(20.3 \%)$

$27(7.7 \%)$

Condom use

Yes

OC use u $^{* * *}$

$117(33.43 \%)$

$233(66.57 \%)$

$227(97.4 \%)$

0.060

Yes

No

$155(44.29 \%)$

$195(55.71 \%)$

$146(94.2 \%)$

$9(5.8 \%)$

$192(98.5 \%)$

$3(1.5 \%)$

\section{Smoking}

Smoker/ex-smoker

Never smoked

$$
\begin{aligned}
& 76(21.71 \%) \\
& 274(78.29 \%)
\end{aligned}
$$

$70(92.1 \%)$

$6(7.9 \%)$

$268(97.8 \%)$

$6(2.2 \%)$

\section{Drinks alcoholic beverages}

$\begin{array}{lccc}\text { Yes } & 162(46.29 \%) & 155(95.7 \%) & 7(4.3 \%) \\ \text { No } & 188(53.71 \%) & 183(97.3 \%) & 5(2.7 \%)\end{array}$

\section{Vaccinated against HPV ${ }^{\S}$}
Yes
$24(6.86 \%)$
$23(95.8 \%)$
$1(4.2 \%)$
No
$326(93.14 \%)$
$315(96.6 \%)$

0.639

0.354

0.039

1.000

Source: research data, 2017.

" $n=$ absolute number; ${ }^{\dagger} p=$ values statistically significant when $<0.20$ for the chi-squared test; ${ }^{*}$ Brazilian minimum wage calculated based on the January 1 st, 2017 , value; ${ }^{* * *} O C=$ oral contraceptive; ${ }^{5} H P V=$ human papillomavirus. 
Table 2 - Analysis of the gynecological, reproductive, and sexual behavior variables of women attended in a Health Unit, according with the results of cytopathology exams in the city of Francisco Beltrão, PR, Brazil, 2017.

$\begin{array}{ccccc}\text { Categorized variables } & \begin{array}{c}\text { Study } \\ \text { population } \\ \left(n^{*}=350\right)\end{array} & \begin{array}{c}\text { Normal } \\ \text { cytopathology } \\ \text { exam }\left(n^{*}=338\right)\end{array} & \begin{array}{c}\text { Abnormal } \\ \text { cytopathology } \\ \text { exam }\left(n^{*}=12\right)\end{array} & \text { P-value }^{\dagger}\end{array}$

Age during first sexual intercourse

0,043

$\leq 18$ years old

$>18$ years old

\section{Number of partners}

$$
\begin{aligned}
& \text { Up to one } \\
& \geq \text { two }
\end{aligned}
$$

$$
\begin{aligned}
& 243(69.43 \%) \\
& 107(30.57 \%)
\end{aligned}
$$

$$
\begin{aligned}
& 231(95.1 \%) \\
& 107(100 \%)
\end{aligned}
$$

$12(100 \%)$

$0(0 \%)$

\subsection{9}

$$
\begin{array}{ccc}
142(40.57 \%) & 142(100 \%) & 0(0 \%) \\
208(59.43 \%) & 196(94.2 \%) & 12(5.8 \%)
\end{array}
$$

\section{Number of new partners in} the year

$\begin{array}{llll}\text { None } & 282(80.57 \%) & 272(96.8 \%) & 9(3.2 \%) \\ \geq 01 & 68(19.43 \%) & 65(95.6 \%) & 3(4.4 \%)\end{array}$

Parity

$$
\begin{aligned}
& \text { Up to two children } \\
& \text { More than two children }
\end{aligned}
$$

\section{STI history ${ }^{\ddagger}$}

$\begin{array}{lr}\text { Yes } & 30(8.6 \%) \\ \text { No } & 320(91.4 \%)\end{array}$

HPV history ${ }^{\S}$

$\begin{array}{lccc}\text { Yes } & 22(6.3 \%) & 19(86.4 \%) & 3(13.6 \%) \\ \text { No } & 328(93.7 \%) & 319(97.3 \%) & 9(2.7 \%)\end{array}$

\section{Performs oral sex}

\author{
Yes \\ No \\ Vaginal infection diagnosis
}

$251(96.2 \%)$

$87(97.8 \%)$

$10(3.8 \%)$

$2(2.2 \%)$

0.904

\subsection{0}

$\begin{array}{ll}26(86.7 \%) & 4(13.3 \%) \\ 312(97.5 \%) & 8(2.5 \%)\end{array}$

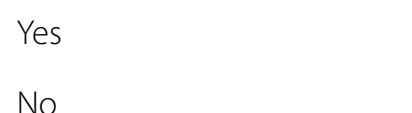

\section{Previos cytopathology diagnosis}

$$
\begin{aligned}
& 138(39.43 \%) \\
& 212(60.57 \%)
\end{aligned}
$$

$\begin{array}{lll}236(67.43 \%) & 109(95.6 \%) & 5(4.4 \%) \\ 114(32.57 \%) & 229(97.0 \%) & 7(3.0 \%)\end{array}$

$134(97.1 \%)$

$4(2.9 \%)$

$8(3.8 \%)$

0.035

0.889

0.711

$<0.001$

$\begin{array}{ccc}325(97.7 \%) & 316(97.5 \%) & 8(2.5 \%) \\ 7(2.1 \%) & 4(57.1 \%) & 3(42.9 \%)\end{array}$

Source: research data, 2017.

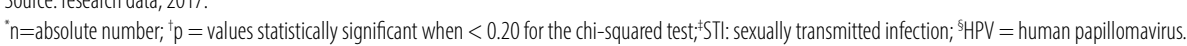


In the univariate regression evaluation, it was found that the main variable with explanatory power for the outcome was a previous cytopathology result, which, being altered in the population being studied, increased the odds of this diagnosis being repeated later more than 30 times. In addition to a number of sexual partners equal or above two (OR:6,575; $\left.\mathrm{IC}_{95 \%} 1,419-30,468\right)$, the STI history (OR:6,000; $I \mathrm{C}_{95 \%} 1,693-$ $21,262)$, including HPV (OR:5,596; IC $\left.C_{95 \%} 1,399-22,384\right)$, the use of OC (OR:3,945; IC 95\% $\left._{1}, 049-14,831\right)$ and smoking (OR:3,829; $\left.\mathrm{IC}_{95 \%} 1,198-12,234\right)$ are considered factors that increase the chance of outcomes with alterations (Table 3).

According to the analysis of the logistic regression, these variables were inserted one by one, starting with lower significance levels, to create a multivariate model. The variables that remained were previous cytopathology diagnosis ( $\mathrm{OR}=25.93$; $\left.\mathrm{Cl}_{95 \%} 3.695-178.667\right)$, smoking (OR=7.576; $\mathrm{Cl}_{95 \%}$ 1.446-39.700), and the use of $\mathrm{OC}\left(\mathrm{OR}=5.265 ; \mathrm{Cl}_{95 \%}\right.$ 1.67-20.275). The findings reiterate that previous diagnosis of cervical alterations, in addition to smoking and OC, can increase the likelihood of negative outcomes to repeat in the population being studied, showing the highest explanatory power of the whole analysis $\left(R^{2}=0.07\right.$ ) (Table 2). Also in the multivariate logistic regression analysis, when the variables smoking and use of contraceptives were associated with previous cytopathology diagnoses, they were, respectively, more than seven times and more than five times more likely to be associated with the outcome of cervical alterations.

\section{DISCUSSION}

The diagnostic of cytopathology changes in the cervix require follow up and treatment so changes can be reversed, minimizing the chances of it evolving into cervical cancer. The prevalence of cervical abnormalities in this study was $3.4 \%$, lower than that of other national researches carried out in the South and in the Northernmost areas of the country, in the states of Rio Grande do Sul (5.7\%)(12) and Pará (5.7\%) (13). The rate was also lower than that of developed countries, such as the United States (6.8\%), United Kingdom (5.2\%), and Norway (5.0\%), whose rates of mortality by cervical cancer are still low ${ }^{(14)}$. Therefore, the findings of this research, which was carried out in a small Brazilian city, in spite of the fact that Brazil is a developing country, show a good conduct in the procedures of collection, analysis, treatment, and monitoring of the gynecological health of the female population, revealing the prevalence found here.

Considering cervical alterations categories found, the LSIL were the most common epithelial alterations (41.7\%). With a prevalence higher than the national one (27.6\%), this diagnosis is the second most commonly described, constituting $0.8 \%$ of all cytopathology exams in the coun$\operatorname{try}^{(3)}$. Most of the times, the LSIL express the HPV infection in cytological manifestations, spontaneously regressing and reducing the chances of progressing into cancer. However, the progression to HSIL can take place, leading ultimately to an invasive carcinoma ${ }^{(3)}$, especially when associated to other factors.

Directives from the Ministry of Health ${ }^{(3)}$ and from the Pan American Health Organization ${ }^{(15)}$ define the age group from 25 to 64 years old as the one who should undergo the preventive pap smear. This work included women both above and below these age limits. The results found showed that $16.6 \%$ of those who have some type of cervical alterations were from 19 to 21 years old. The abnormality found was classified as a LSIL. Some authors have reported a growth in cervical lesions in the younger population, who, today, is not considered to be the target audience for the pap smear test. A research found that $20 \%$ of lesions in the cervix affected women below 19 years old, including high-grade lesions ${ }^{(8)}$. Another yielded similar findings, with an expressive number of adolescents with alterations (12.4\%), especially LSIL, in cities from the state of Rio de Janeiro ${ }^{(10)}$. A research described different characteristics about the population with cervical cancer in Brazil from 2000 to 2009, finding that 3\% of women with neoplasms were younger than 25 , while $17 \%$ were older than 64 years old ${ }^{(16)}$. Another study, carried out in the city of Maringá, Paraná, showed that 10.9\% and 13.9\% of atypical cells (including LSIL and HSIL) diagnosed in the female public in the research were found in the group from 12 to 24 and above 60 years old, respectively ${ }^{(7)}$. This work did not find cases of women above 64 years old with cervical alterations, as some others did. However, the lesions found in participants below 24 years old signs to the potential need for adaptations in the screening strategies for the prevention of cervical cancer.

The multivariate regression analysis of the outcome cytopathology alterations in the cervix indicated potential risk factors, such as a history of previous altered cytopathology exams, smoking, and OC use. Regarding the first, the chance for a cytopathology exam to be negative may be as high as $80 \%$ if the two previous ones also were ${ }^{(3)}$. In this study, the multivariate model suggests that, when the previous result indicated cervical alterations, the chance for the current exam to indicate the same is 25 times greater. The Ministry of Health recommends follow up with monitoring cytological exams for those with diagnosed cervical intraepithelial lesions. However, some authors find that there is a low adherence from the population attended in Primary Health Care Units 
Table 3 - Odds ratio (OR), confidence interval, and $R^{2}$ of the univariate and multivariate logistic regression model for variables associated with the outcome cytopathology alterations in the population under study, in the city of Francisco Beltrão, PR, Brazil, 2017

\begin{tabular}{|c|c|c|c|c|c|c|}
\hline Associated variables & $\begin{array}{l}\text { OR }{ }^{*} \text { univariate } \\
\left(\mathrm{Cl}^{+} 95 \%\right)\end{array}$ & P-value ${ }^{\ddagger}$ & $\mathbf{R}^{2 \S}$ & $\begin{array}{l}\text { OR multivariate } \\
\left(\mathrm{Cl}^{+} 95 \%\right)\end{array}$ & P-value ${ }^{\ddagger}$ & $\mathbf{R}^{2 \S}$ \\
\hline
\end{tabular}

Age group

Age $\geq 38$ years old

Age $<38$ years old

$2.794(0.825-9.461)$

0.099

0.008

Age at the first sexual intercourse $\leq 18$ years old

No

Yes

$>1.00$ (l)

$0.996 \quad 0.025$

Number of sexual partners

through life $\geq 2$
No
1
Yes
$6.575(1.419-30.468)$
$\mathbf{0 . 0 1 6} 0.023$

STI history"

No

Yes

$6.000(1.693-21.262)$

$\mathbf{0 . 0 0 6} \quad 0.017$

HPV history ${ }^{* *}$

No

Yes

$5.596(1.399-22.384)$

$\mathbf{0 . 0 1 5} 0.013$

\section{Previous}

cytopathology exam

Normal

Abnormal

$29.625(5.671-154.757)$

$<0.000$

0.035

25.693 (3.695-178.667)

0.001

OC use

No

Yes

1

$3.945(1.049-14.831)$

$\mathbf{0 . 0 4 2} \quad 0.014 \quad 5.265(1.367-20.275)$

$\mathbf{0 . 0 1 7} \quad 0.070$

\section{Smoking}

No

Yes

$3.829(1.198-12.234)$

0.024

$0.014 \quad 7.576(1.446-39.700)$

0.016

Source: research data, 2017.

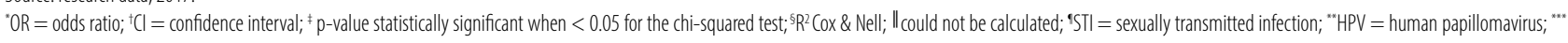
$O C=$ oral contraceptive 
(UBS), with only 7.3\% continuing the diagnostic exams for alterations ${ }^{(17)}$. This study did not analyze the follow up of users with an altered preventive exam. However, it is undeniable that this can contribute for the progression towards more serious lesions, which shows the importance of a later diagnostic follow up.

Among the life habits, the use of $\mathrm{OC}$ and smoking were other risk factors identified. Respectively, they increased more than five and almost seven times, respectively, the chance of cervical alterations, when combined with a previous history of altered cytopathology results.

Regarding the use of OC, the findings confirm previous studies ${ }^{(5,18)}$. One of these showed that the intake of contraceptives, regardless of the type, was a risk factor for cervical alterations, and, when associated with the number of sexual partners, made the outcome more likely, corroborating the characteristics of the latter as an independent factor for cervical changes in this research. The $\mathrm{OC}$ increases the incidence of cervical ectropion, a condition in which the columnar epithelium is outside the ectocervix. This situation makes the mucosa vulnerable to the action of carcinogens and various other microorganisms, such as the HPV. The researchers also indicate that the administration of OC, regardless of the type, increases the likelihood of the persistence of HPV, which is the main etiologic agent of cervical lesions, invalidating the natural cleansing process ${ }^{(5)}$. A study carried out with women after transplants, who, therefore, were immunosuppressed, in a public hospital in the city of Niterói, in Rio de Janeiro, found the use of $\mathrm{OC}$ as the only risk factor, and that it increased that chance of STIs more than 7 times ${ }^{(19)}$.

It does not surprise that the results of this work indicate smoking as a potential risk factor for abnormal cytopathology exam results, which was also the case in other researches ${ }^{(18,20)}$. The habit of smoking is, without a doubt, the most significant environmental component for the development of lesions that can led to cervical cancer. Specifically, the more one smokes and the longer one smokes, the greater is the probability that they will be affected by the disease, and when a woman stops smoking this probability diminishes ${ }^{(20)}$. Smoking contributes to develop cervical cancer, reducing the number of Langerhans cells and their functionality, leading to a local immunosuppressant effect caused by the metabolites in tobacco. Related to that, the presence of nicotine and cotinine in the cervical mucus of women who smoke damage the DNA, culminating in the alteration of epithelial cells ${ }^{(20)}$. This study found that smoking increased at least 7.5 times the chance of an altered cytopathology diagnosis. The association of the habit of smoking with the presence of cervical changes not only increases the chances for the persistence of viral infections, such as the HPV, as it also determines the evolution of lesions and the progression towards cancer ${ }^{21,22)}$. Studies have determined that the consumption of tobacco is a risk factor for alterations found in the pap smear test, even for passive smokers, with an increase of 1.7 times and 1.45 for the non-passive ${ }^{(19)}$. Another study found an increase of $43 \%$ in the risk of CINs (Cervical Intraepithelial Neoplasias) in the female population who both use OC and are smokers, in agreement with this study ${ }^{(23)}$.

Although the variables related with the beginning of sex life and the number of partners are not part of the likely regression model, the results have shown that women who start their sexual relations before 18 years old and have at least two partners through life are the group with abnormalities in the cervical epithelium. Investigations on the theme have shown that both sexual relations in early age as several partners increase the chances of viral infections and lesions precursor to cervical cancer ${ }^{(22)}$. This situation is based on the fact that women whose sexarche is too early are also exposed to infections for long periods of time, when compared to those who started their sex life later, maximizing the risk of infection for each sexual partner ${ }^{(8)}$. The history of STIs was an independent risk factor for the outcome, and it can increase chances of later cervical changes, leading to inflammations, breaking the epithelium and making the access to pathogens such as HPV possible.

In regard to the limitations of this study, the questionnaire used for the investigation of risk factors and to characterize the group may have led to prevarication bias, considering that the responses could contain imprecisions or omissions due to several reasons, such as embarrassment, fear, or forgetfulness. Another limitation may have been the convenience sample from health units, which was not random, even though these units are distributed throughout the city.

\section{$\square$ CONCLUSION}

The prevalence of cervical changes found in this study was 3.4\%, and the possible risk factors for the female population were previous history of abnormal pap smear results, smoking, and using OC, according with a multivariate regression model. Another important finding of the study was the detection of LSIL in younger women, who are below the recommended age for the test, although elders out of the range of the test showed no abnormality. As opposed to most researches that seek to find what are the risks related to HPV infections and to the development of cancer, this study emphasized exclusively cervical abnormalities as its main outcome, which could be affected by regional specificities. Getting to know these particularities and risk factors for cervix abnormalities is essential to characterize the target population who is apt 
to develop this diagnosis. Furthermore, it can contribute for preventive health measures, minimizing the progression towards more serious lesions and cancer.

\section{REFERENCES}

1. Bray F, Ferlay J, Soerjomataram I, Siegel RL, Torre LA, Jemal A. Global Cancer Statistics 2018: GLOBOCAN estimates of incidence and mortality worldwide for 36 cancers in 185 countries. CA Cancer J Clin. 2018;68(6):394-424. doi: https:// doi.org/10.3322/caac.21492

2. Ministério da Saúde (BR), Instituto Nacional de Câncer José Alencar Gomes da Silva. Controle do Câncer de colo do útero [Internet]. Rio de Janeiro: INCA; c2019 [cited 2019 Ago 28]. [about 2 screens] Available from: http://www2.inca.gov. br/wps/wcm/connect/tiposdecancer/site/home/colo_utero/definicao

3. Ministério da Saúde (BR). Instituto Nacional de Câncer José Alencar Gomes da Silva. Diretrizes brasileiras para o rastreamento do câncer do colo do útero. 2. ed. rev. ampl. atual. Rio de Janeiro: INCA; 2016 [cited 2019 Jul 24]. Available from: https://www.inca.gov.br/sites/ufu.sti.inca.local/files//media/document// diretrizesparaorastreamentodocancerdocolodoutero_2016_corrigido.pdf

4. Mignot S, Ringa V, Vigoureux S, Zins M, Panjo H, Saulnier PJ, et al. Pap tests for cervical cancer screening test and contraception: analysis of data from the CONSTANCES cohort study. BMC Cancer. 2019;19(1):317. doi: https:/doi. org/10.1186/s12885-019-5477-8

5. Volpato LK, Siqueira IR, Nunes RD, Piovezan AP. Association between hormonal contraception and injuries induced by human papillomavirus in the uterine cervix. Rev Bras Ginecol Obstet. 2018;40(4):196-202. doi: https://doi. org/10.1055/s-0038-1642603

6. Cavalheiri JC, Alves MB, Teixeira GT, Trevisan MG, Costa LD, Perondi AR. Fatores de risco para alterações citopatológicas cervicais em pacientes atendidas em unidade de saúde. Publ UEPG Ci Biol Saúde. 2018;24(1):48-61. doi: https://doi. org/10.5212/Publ.Biologicas.v.24i1.0007

7. Dell'Agnolo CM, Brischiliari SCR, Saldanc G, Gravena AAF, Lopes TCR, Demitto M0, et al. Avaliação dos exames citológicos de Papanicolau em usuárias do Sistema Único de Saúde. Rev Baiana Saúde Pública. 2014 [cited 2020 Apr 12] ;38(4):854-64. Available from: http://files.bvs.br/upload/S/0100-0233/2014/ v38n4/a4913.pdf

8. Monteiro DL, Trajano AJ, Silva KS, Russomano FB. Incidence of cervical intraepithelial lesions in a population of adolescents treated in public health services in Rio de Janeiro, Brazil. Cad Saúde Pública. 2009;25(5):1113-22. doi: https://doi. org/10.1590/50102-311X2009000500018

9. Ruggeri JB, Agnolo CMD, Gravena AAF, Demitto MO, Lopes TCR, Delatorre $S$, et al. Treatment and follow-up of human papillomavirus infected women in a municipality in southern Brazil. Asian Pac J Cancer Prev. 2015;16(15):6521-6. doi: https://doi.org/10.7314/APJCP.2015.16.15.6521

10. Pedrosa ML, Mattos IE, Koifman RJ. Lesões intra-epiteliais cervicais em adolescentes: estudo dos achados citológicos entre 1999 e 2005, no município do Rio de Janeiro, Brasil. Cad Saúde Pública. 2008;24(12):2881-90. doi: https://doi.org/10.1590/ S0102-311X2008001200017
11. Medeiros-Verzaro P, Sardinha AHL. Caracterização sociodemográfica e clínica de idosas com câncer do colo do útero. Rev Salud Pública. 2018;20(6):718-24. doi: https://doi.org/10.15446/rsap.V20n6.69297

12. Coser J, Boeira TR, Wolf JM, Cerbero K, Simon D, Lunge VR. Cervical human papillomavirus infection and persistence: a clinic-based study in the countryside from South Brazil. Braz J Infect Dis. 2016;20(1):61-8. doi: https:/doi.org/10.1016/j. bjid.2015.10.008

13. Rocha SMM, Bahia MO, Rocha CAM. Profiles of cervical screening tests performed in Casa da Mulher, Pará State, Brazil. Rev Pan-Amaz Saúde. 2016;7(3):51-5. doi: https://doi.org/10.5123/S2176-62232016000300006

14. Bortolon PC, Silva MAF, Corrêa FM, Dias MBK, Knupp VMA0, Assis M, et al. Quality Evaluation of Cervical Cytopathology Laboratories in Brazil. Rev Bras Cancerol. 2012 [cited 2019 Aug 02];58(3):435-44. Available from: http://www1.inca. gov.br/rbc/n_58/v03/pdf/13_artigo_avaliacao_qualidade_laboratorios_ citopatologia_colo_utero_brasil.pdf

15. Organização Pan-Americana da Saúde. Controle integral do câncer do colo do útero: guia de práticas essenciais. Washington (DC): OPAS; 2016 [cited 2019 Jul 24]. Available from: https://iris.paho.org/bitstream/hand le/10665.2/31403/9789275718797-por.pdf?sequence=1\&isAllowed=y

16. Thuler LCS, Bergmann A, Casado L. Perfil das pacientes com câncer do colo do útero no Brasil, 2000-2009: estudo de base secundária. Rev Bras Cancerol. 2012;58(3):351-7.doi: https://doi.org/10.32635/2176-9745.RBC.2012v58n3.583

17. Dalmolin SP,Dexheimer GM, Delving LKOB. Mulheres com exames citopatológicos alterados: Avaliação do seguimento de acordo com as condutas preconizadas pelo Ministério da Saúde. RBAC. 2016 [cited 2019 Jul 24];48(3):235-9. Available from: http://www.rbac.org.br/wp-content/uploads/2016/11/ARTIG0-8_RBAC48-3-2016-ref.-444.pdf

18. Sanjosé S, Brotons M, Pavón MA. The natural history of human papillomavirus infection. Best Pract Res Clin Obstet Gynaecol. 2018;47:2-13. doi: https://doi. org/10.1016/j.bpobgyn.2017.08.015

19. Martins CAO, Guimarães ICCDV, Velarde LGC. Relationship between the risk factors for human papillomavirus infection and lower genital tract precursor lesion and cancer development in female transplant recipients. Transpl Infect Dis. 2017;19(4):e12714. doi: https://doi.org/10.1111/tid.12714

20. Feng RM, Hu SY, Zhao F, Zhang R, Zhang X, Al Wallach, et al. Role of active and passive smoking in high-risk human papillomavirus infection and cervical intraepithelial neoplasia grade 2 or worse. J Gynecol Oncol. 2017;28(5):e47. doi: https:/doi.org/10.3802/jgo.2017.28.e47

21. Ward KK, Berenson AB, Breitkopf CR. Passive smoke exposure and abnormal cervical cytology in a predominantly Hispanic population. Am J Obstet Gynecol. 2011;204(3):213.e1-6. doi: https://doi.org/10.1016/j.ajog.2010.10.909

22. Makuza JD, Nsanzimana S, Muhimpundu MA, Pace LE, Ntaganira J, Riedel DJ. Prevalence and risk factors for cervical cancer and pre cancerous lesions in Rwanda. Pan Afr Med J. 2015;22:26. doi: https:/doi.org/10.11604/pamj.2015.22.26.7116

23. Xu H, Egger S, Velentzis LS, O'Connell DL, Banks E, Darlington-Brown J, et al. Hormonal contraceptive use and smoking as risk factors for high-grade cervical intraepithelial neoplasia in unvaccinated women aged 30-44 years: a case-control study in New South Wales, Australia. Cancer Epidemiol. 2018;55:162-9. doi: https:/ doi.org/10.1016/j.canep.2018.05.013 
- Authorship contributions:

Concept - Indianara Carlotto Treco; Léia Carolina Lucio. Data selection - Indianara Carlotto Treco; Valquíria Kulig Vieira; Janaína Carla da Silva; Fernando Rodrigo Treco; Léia Carolina Lucio.

Formal analysis - Indianara Carlotto Treco; Lirane Elize Defante Ferreto; Léia Carolina Lucio.

Investigation - Indianara Carlotto Treco; Valquíria Kulig Vieira; Janaína Carla da Silva; Fernando Rodrigo Treco;

Léia Carolina Lucio.

Methodology - Indianara Carlotto Treco; Léia Carolina

Lucio.

Project administration - Indianara Carlotto Treco; Léia

Carolina Lucio.

Resources - Indianara Carlotto Treco; Léia Carolina

Lucio.

Supervision - Indianara Carlotto Treco; Léia Carolina

Lucio.

Validation - Indianara Carlotto Treco; Léia Carolina

Lucio.

Visualization - Indianara Carlotto Treco; Fernando

Rodrigo Treco; Léia Carolina Lucio.

Writing - original draft - Indianara Carlotto Treco; Léia

Carolina Lucio.

Writing - revision and editing - Indianara Carlotto

Treco; Fernando Rodrigo Treco; Lirane Elize Defante

Ferreto; Léia Carolina Lucio.

The authors declare no conflict of interest.

\section{- Corresponding author:}

Léia Carolina Lucio

E-mail: leiacarol@gmail.com

Editor-in-chief:

Maria da Graça Oliveira Crossetti 